\title{
Successful in vitro cultivation of Borrelia duttonii and its comparison with Borrelia recurrentis
}

\author{
S. J. Cutler, ${ }^{1}$ C. O. K. Akintunde, ${ }^{1}$ J. Moss, ${ }^{1}$ M. Fukunaga, ${ }^{2}$ K. Kurtenbach, ${ }^{3}$ \\ A. Talbert, ${ }^{4}$ H. Zhang, ${ }^{1}$ D. J. M. Wright ${ }^{1}$ and D. A. Warrell ${ }^{5}$
}

Author for correspondence: S. J. Cutler. Tel: +44 1818467570. Fax: +44 1818467261.

e-mail: s.cutler@ic.ac.uk

1 Imperial College School of Medicine (Infectious Diseases \& Medical Microbiology; Central Biomedical Services; Department of Histopathology; and Molecular Pathology), Charing Cross Campus, London, UK

2 Department of Molecular Microbiology, Fukuyama University, Hiroshima, Japan

${ }^{3}$ The Wellcome Trust Centre for the Epidemiology of Infectious Disease, University of Oxford, Oxford, UK

4 Mvumi Hospital, PO Box 32, Mvumi, Dodoma, Tanzania

5 Centre for Tropical Medicine, John Radcliffe Hospital, Oxford, UK
Borrelia duttonii, the cause of East African tick-borne relapsing fever, has until now been refractory to growth in laboratory media. This spirochaete has only be propagated in mice or by tissue culture, restricting both yield and purity of cells available for research. The successful isolation of five clinical isolates of $B$. duttonii from patients in Central Tanzania and their comparison with Borrelia recurrentis is reported. Electron microscopy revealed spirochaetal cells with pointed ends, a mean wavelength of $1.8 \mu \mathrm{m}$ with an amplitude of $0.8 \mu \mathrm{m}$, similar to the findings for $B$. recurrentis. Cells contained 10 periplasmic flagella inserted at each end of the spirochaete, again comparable with the counts of 8-10 flagella found in B. recurrentis. PFGE revealed a chromosome of approximately $1 \mathrm{Mb}$, a large plasmid of approximately $200 \mathrm{~kb}$, and a small plasmid of $11 \mathrm{~kb}$ in all strains of B. duttonii and in B. recurrentis. B. duttonii possessed a further 7-9 plasmids with sizes ranging from 20 to $90 \mathrm{~kb}$. In two isolates of $B$. duttonii, the profiles were identical. In contrast, all 18 isolates of B. recurrentis fell into one of five plasmid patterns with 3-4 plasmids ranging from 25 to $61.5 \mathrm{~kb}$ in addition to those of 11 and $200 \mathrm{~kb}$ described above. Analysis of the SDS-PAGE profiles of B. duttonii strains revealed a highmolecular-mass band of 33.4-34.2 kDa in four strains (variable large protein, VLP) and a low-molecular-mass band of $22.3 \mathrm{kDa}$ in the remaining strain (variable small protein, VSP). This resembles the protein profiles found in $B$. recurrentis. The $G+C$ ratio of $B$. duttonii was $27.6 \mathrm{~mol} \%$. Nucleotide sequence of the rrs gene (16S rRNA) from four $B$. duttonii isolates revealed $100 \%$ identity among these strains and $99.7 \%$ homology with three strains deposited by others in GenBank. The rrs gene of eight representative clinical isolates of B. recurrentis confirmed their close similarity with $B$. duttonii.

Keywords: Borrelia duttonii; Borrelia recurrentis

\section{INTRODUCTION}

Borrelia duttonii, the cause of East African relapsing fever, is transmitted by the bite of the soft-bodied tick Ornithodoros moubata. Tick-borne relapsing fever is endemic in central Tanzania, particularly the Singida,

Abbreviations: VLP, variable large protein; VSP, variable small protein. The GenBank accession numbers for the rrs gene sequences of $B$. duttonii and $B$. recurrentis strain A1 are AF107363-AF107366 (for B. duttonii strains $\mathrm{Ku}, \mathrm{Ly}, \mathrm{La}$ and Ma, respectively), AF107367 (for the A1 strain of $B$. recurrentis) and AF107356-AF107362 (for $B$. recurrentis strains A4, A5, $A 8, A 10, A 17, A 11$ and $A 16$, respectively).
Dodoma, Kigoma and Mwanza regions (Jongen et al., 1997). In the Dodoma region, the Gogo form the predominant tribe. Most are small farmers and live in traditional dwellings (Tembe) constructed of mud, with flat, earth-covered roofs. The occupants sleep on the floor on animal skins, and frequently share their accommodation with small livestock. Approximately $87.2 \%$ of traditional mud dwellings are infested with O. moubata (Barclay \& Coulter, 1990) living in close proximity with man. Nocturnal tick feeding usually passes unnoticed, with feeding times of up to $30 \mathrm{~min}$ (Walton, 1962). Infection with $B$. duttonii is the sixth highest cause of admissions and the seventh highest 
cause of mortality among children at Mvumi Hospital in the Dodoma region of Tanzania (Talbert et al., 1998). The annual incidence in this area has been estimated at 163/1000 children under 5 years, and 384/1000 children under 1 year (Barclay \& Coulter, 1990). While in pregnancy tick-borne relapsing fever is associated with a considerable perinatal mortality (436/1000 births) and foetal miscarriage rate of $475 /$ 1000 pregnancies (Jongen et al., 1997).

Relapsing fever may range from subclinical with mild spirochaetaemia to severe form, with a mortality of 4-5\% (Melkert, 1991). Higher spirochaete counts are usually associated with a poorer prognosis. As seen in the louse-borne disease, the level of spirochaetaemia correlates with the disease severity. Adult acute complications include jaundice, hepatomegaly, pneumonia and mental confusion (Melkert, 1991).

Both $B$. duttonii tick-borne and louse-borne relapsing fever are considered to be diseases in which man is the only reservoir. Both spirochaetes are fastidious and until recently were considered non-cultivable. However, unlike Borrelia recurrentis, $B$. duttonii will infect laboratory mice. Prior to this study, research on $B$. duttonii has been restricted by the amount of material that can be collected from mice. An in vitro cell culture method was described using Sf1Ep cells, which could provide more cellular material, but has not been widely adopted (Konishi et al., 1993).

We now describe the cultivation of $B$. duttonii from patients in Mvumi, Central Tanzania, despite earlier failed attempts to grow B. duttonii as recently as 1997 (Dupont et al., 1997). We used the same technique by which we were able to culture $B$. recurrentis for the first time (Cutler et al., 1994). The initial characterization of these clinical isolates of $B$. duttonii are presented and compared with the closely related louse-borne $B$. recurrentis.

\section{METHODS}

Tick-borne relapsing fever patients. Samples were collected over a 2 week period in May 1998, shortly after the Tanzanian rainy season. Patients were brought to Mvumi hospital from the surrounding catchment area. All patients were demonstrated to be spirochaetaemic by blood film microscopy using Field's stain. Blood samples were collected from 12 patients either by venepuncture or collected in glass capillary tubes. Four patients were female and the remaining eight were male. Ages ranged from 4 months to 5 years (ages not recorded for two patients). Blood was inoculated into BSK II and incubated at room temperature (incubator not available). Cultures were blindly passaged every third day into fresh BSK II.

Bacterial strains and culture conditions. All spirochaetes were cultured in BSK II medium (Barbour, 1984), using BSA fraction V recommended by Sigma for inclusion in BSK II medium. It was necessary to test each batch of albumin for its ability to grow relapsing fever borrelia as over two-thirds failed to promote sufficient growth. Strains were maintained by either twice or thrice weekly subculture incubated at $33{ }^{\circ} \mathrm{C}$. Borrelia were passaged $6-15$ times in vitro before analysis. This was the minimum level of passages to obtain sufficient material to undertake the study. The $B$. recurrentis strains used in this study have been described elsewhere (Cutler et al., 1997).

Contaminated cultures were passaged through antibioticcontaining BSK II either containing $100 \mu \mathrm{g}$ rifampicin $\mathrm{ml}^{-1}$ and $100 \mu \mathrm{g}$ 5-fluorouracil $\mathrm{ml}^{-1}$ or additionally containing $50 \mu \mathrm{g}$ colistin sulphate $\mathrm{ml}^{-1}$. One culture contaminated with a filamentous fungus was purified using $100 \mu \mathrm{g}$ amphotericin $\mathrm{B} \mathrm{ml}{ }^{-1}$.

SDSPAGE and immunoblotting. Borrelial proteins were stacked using a $4 \%(\mathrm{v} / \mathrm{v})$ stacking gel, then separated by discontinuous SDS-PAGE using $14 \%(\mathrm{v} / \mathrm{v})$ gels run at $150 \mathrm{~V}$ (mini-gels) or $200 \mathrm{~V}$ for large gels according to previously described methods (Cutler et al., 1997).

Mini SDS-PAGE gels, as described above, were blotted onto nitrocellulose membranes as described elsewhere (Cutler et al., 1993). The membranes were incubated at room temperature overnight with a genus-specific anti-borrelial flagellin mAb H9724 (Barbour et al., 1986), used at a 1:1000 (v/v) dilution to locate this band in B. duttonii isolates. After washing the membrane was incubated with a $1: 3000(\mathrm{v} / \mathrm{v})$ dilution of goat anti-mouse-alkaline phosphatase conjugate (Bio-Rad), washed and developed using NBT/BCIP ( $p$-nitro blue tetrazolium chloride $0.3 \mathrm{mg} \mathrm{ml}^{-1}$ and 5-bromo-4chloro-3-indolyl phosphate $p$-toluidine salt $0.15 \mathrm{mg} \mathrm{ml}^{-1}$ ). A polyclonal rabbit anti-Borrelia hermsii VSP33 (kindly provided by Dr Alan Barbour; Barbour et al., 1983), was used to test its reactivity with the isolates at a 1:400(v/v) dilution. For these immunoblots, anti-rabbit-alkaline phosphatase conjugate was used at 1:3000 (v/v) dilution.

PFGE. Cells for PFGE were adjusted to optical density 2 at $600 \mathrm{~nm}$ and prepared as agarose blocks, and the DNA extracted as described elsewhere (Cutler et al., 1997). These blocks were then loaded into $200 \mathrm{ml} \mathrm{1.2 \%} \mathrm{(w/v)} \mathrm{agarose} \mathrm{gels}$ and run in $0.5 \%$ TBE $(0.045 \mathrm{M}$ Tris-borate and $0.001 \mathrm{M}$ EDTA) using the Pharmacia Gene Navigator. Lambda ladder, $8-48 \mathrm{~kb}$ and a $5 \mathrm{~kb}$ ladder pulsed-field markers (BioRad) were included on every gel. The gels were run using either $150 \mathrm{~V}$ with pulse times from 0.5 to $45 \mathrm{~s}$ for a total of 30 $\mathrm{h}$, or $200 \mathrm{~V}$ with pulse times from 0.5 to $15 \mathrm{~s}$ for $17 \mathrm{~h}$. Bands were visualized following ethidium bromide staining ( $1 \mu \mathrm{g}$ $\mathrm{ml}^{-1}$ ) for $1 \mathrm{~h}$.

$\mathbf{G}+\mathbf{C}$ Content of DNA. The $\mathrm{G}+\mathrm{C}$ content of $B$. duttonii strain Ly, was determined using HPLC as described by Cutler et al. (1997).

DNA sequencing. The rrs gene was sequenced from four of the five $B$. duttonii strains. The remaining $B$. duttonii strain was omitted as it was regarded as identical to one included in sequencing (see Results and Discussion). Representative strains of $B$. recurrentis protein groups $1-4$ and plasmid types 1-5 (Cutler et al., 1997) were also sequenced. Following overnight cell lysis at $56^{\circ} \mathrm{C}$ in buffer containing $10 \mathrm{mM}$ Tris $(\mathrm{pH} 8), 60 \mathrm{mM}$ EDTA (pH 8), 5\% (w/v) SDS and $50 \mu \mathrm{g}$ proteinase $\mathrm{K} \mathrm{ml}^{-1}$, DNA was phenol/chloroform-extracted, ethanol-precipitated and washed with $70 \%(\mathrm{v} / \mathrm{v})$ ethanol. Initial amplification of the rrs gene used a $50 \mu$ l reaction volume with primers UniB and fD3 $(0.5 \mu \mathrm{M})$; dNTPs $200 \mu \mathrm{M}$; Promega Buffer A [50 mM KCl; $10 \mathrm{mM}$ Tris/HCl, $\mathrm{pH} 9.0 ; 0.1 \%(\mathrm{v} / \mathrm{v})$ Triton $\mathrm{X}-100) ; 2.5 \mathrm{mM}$ magnesium chloride; $1 \mathrm{ng}$ template DNA; and $0.125 \mathrm{U}$ Taq polymerase (Promega). Amplification was done using a Perkin Elmer thermocycler (model 9600) with 35 cycles of denaturation at $94{ }^{\circ} \mathrm{C}$ for $1 \mathrm{~min}$; annealing at $53{ }^{\circ} \mathrm{C}$ for $45 \mathrm{~s}$; and extension 
at $72{ }^{\circ} \mathrm{C}$ for $1.5 \mathrm{~min}$. Products were purified using a QIAquick PCR purification kit (Qiagen) according to the manufacturer's instructions. DNA quantification was by comparison with HaelII digested $\phi$ X174 DNA markers in $1 \cdot 2 \%(\mathrm{w} / \mathrm{v})$ agarose gels.

DNA was sequenced in each direction using the overlapping primers fD3-500R, 400F-900R, 800F-1050R and 1050FrD1 described by Marti Ras et al. (1996). Primers were used at $3 \cdot 2 \mathrm{pmol} \mu \mathrm{l}^{-1}$ with $4 \mu \mathrm{l}$ Bigdye enzyme, $1-3 \mu \mathrm{l}$ DNA (approx. $100 \mathrm{ng}$ ) made up to a final reaction volume of $10 \mu \mathrm{l}$. With the exception of primers 1050 forward and reverse, the amplification conditions were $96{ }^{\circ} \mathrm{C}$ for $10 \mathrm{~s} ; 50{ }^{\circ} \mathrm{C}$ for 5 $\mathrm{s}$; and $60^{\circ} \mathrm{C}$ for $4 \mathrm{~min}$ repeated for 25 cycles. For primers 1050 forward and reverse these conditions were modified by decreasing the annealing temperature to $46{ }^{\circ} \mathrm{C}$ and increasing the cycle number to 35 .

Following cycle sequencing reaction products were ethanolprecipitated on ice for $10 \mathrm{~min}$, and washed in $70 \%(\mathrm{v} / \mathrm{v})$ ethanol. The pellet was dried before loading on sequencing gels. The sequencing gel electrophoresis was performed using a 373 ABI automated DNA sequencer (Applied Biotechnology Centre).

Data were edited using SeqEd (version 1.0.3) and aligned using CLUSTAL v. Consensus sequences derived from both directions were compared with sequences held in GenBank.

Electron microscopy. B. duttonii strain Ly grown in BSK II medium was harvested at $3000 \mathrm{~g}$ for $20 \mathrm{~min}$, washed once in PBS (3000 $g$ for $20 \mathrm{~min}$ ), the pellet resuspended and fixed in $3 \%(\mathrm{v} / \mathrm{v})$ glutaraldehyde in $0.1 \mathrm{M}$ cacodylate buffer, recentrifuged and incubated at $4{ }^{\circ} \mathrm{C}$ for $1 \mathrm{~h}$. Cells were postfixed in $2 \%(\mathrm{w} / \mathrm{v})$ osmium tetroxide, dehydrated in ascending grades of ethanol, and embedded in Spurr's resin. Ultrathin sections were stained with aqueous uranyl acetate and Reynold's lead citrate prior to examination with an electron microscope. To prepare for negative staining, the pellet was resuspended (one part to nine) in $1 \%$ ammonium molybdate neutralized with concentrated ammonium hydroxide. Prior to examination, 1 drop of suspension was allowed to air-dry at room temperature on carbon-coated Formvar films supported on copper grids.

\section{RESULTS}

\section{Isolation of strains}

Viable cultures were obtained from five of the 12 patients. Strains were designated La, Ly, Lw, Ma and $\mathrm{Ku}$. Initially four of these were contaminated ( $\mathrm{La}, \mathrm{Ly}$, $\mathrm{Ma}$ and $\mathrm{Ku}$ ), but were successfully purified by passage through selective inhibitory BSK II.

\section{SDS-PAGE}

Coomassie blue-stained gels showed highly conserved profiles between the $B$. duttonii and $B$. recurrentis isolates with the exception of a major band. Complete identity was seen between strains Ly and Lw with their major protein band being $33.4 \mathrm{kDa}$ (Fig. 1). Strains $\mathrm{La}$ and $\mathrm{Ma}$ also showed major protein bands within this range with molecular masses of $34.2 \mathrm{kDa}$ and $33.7 \mathrm{kDa}$, respectively (Fig. 1). These protein patterns are most like those of protein group 3 of $B$. recurrentis which gave a major band of $35.5 \mathrm{kDa}$ (strain A9; Fig. 1) (Cutler et al., 1997). The remaining

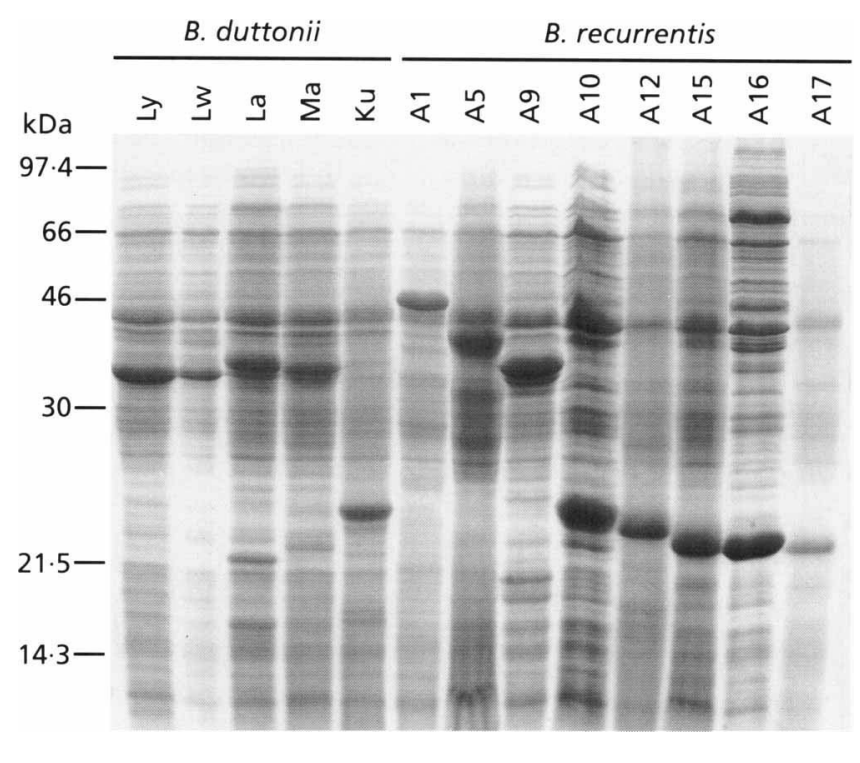

Fig. 1. Coomassie blue-stained SDS-PAGE protein profiles of $B$. duttonii strains together with representative strains of B. recurrentis.

B. duttonii strain, $\mathrm{Ku}$, revealed a band of $22 \cdot 3 \mathrm{kDa}$, comparable with protein group $4 \mathrm{a}$ of $B$. recurrentis (strain A10, Fig. 1). In addition to the major band, strains $\mathrm{La}, \mathrm{Ma}$ and $\mathrm{Ku}$ also showed an extra band in the $19-21 \mathrm{kDa}$ range.

\section{Immunoblotting with borrelial antibodies}

The flagellin protein band located at $41 \mathrm{kDa}$ was detected using mAb H9724 in all isolates of $B$. duttonii (data not shown). Size was determined by comparison to molecular mass markers, the B31 strain of Borrelia burgdorferi sensu stricto, and to B. recurrentis.

Immunoblotting with rabbit polyclonal serum raised against VSP33 of $B$. hermsii showed reactivity with VSP of B. duttonii (strain $\mathrm{Ku}$ ) but failed to react with VLP-expressing strains. The antisera however, reacted to both VSPs (strains A15 and A16) and VLPs (strains $\mathrm{A} 1$ and $\mathrm{A} 9$ ) of $B$. recurrentis (Table 1).

\section{PFGE}

All strains had a linear chromosome with a size of approximately $1 \mathrm{Mb}$. All isolates of $B$. duttonii, like $B$. recurrentis, carried a large plasmid of approximately $200 \mathrm{~kb}$ (range 196-202 kb; Fig. 2), however, the patterns seen for plasmids of $20-90 \mathrm{~kb}$ showed more heterogeneity (Fig. 2). None of the $B$. duttonii isolates resembled $B$. recurrentis by PFGE. Two isolates, Ly and Lw, showed identical PFGE profiles to each other with 11 bands, but were different from the remaining strains with 9-10 bands. As found in B. recurrentis, a plasmid of $11 \mathrm{~kb}$ was present in all strains. This band was not always detectable with ethidium bromidestained gels, only being seen in freshly prepared blocks. The sizes of plasmids belonging to each strain of $B$. 
Table 1. Immunoblot reactivity of antisera raised against VSP33 of $B$. hermsii with representative strains of $B$. duttonii and $B$. recurrentis

Lw, Ly, La, Ma and Ku represent different strains of $B$. duttonii, while A1, A5, A9, A10, A12, A15 and A17 are different strains of $B$. recurrentis representative of the different sized VLP and VSP groups for this species (protein groups 1-4).

\begin{tabular}{|lcccccccccccc|}
\hline $\begin{array}{l}\text { Major expressed } \\
\text { protein }\end{array}$ & VLP & VLP & VLP & VLP & VSP & $\begin{array}{c}\text { VLP } \\
\text { Gp1 }\end{array}$ & $\begin{array}{c}\text { VLP } \\
\text { Gp2 }\end{array}$ & $\begin{array}{c}\text { VLP } \\
\text { Gp3 }\end{array}$ & $\begin{array}{c}\text { VSP } \\
\text { Gp4a }\end{array}$ & $\begin{array}{c}\text { VSP } \\
\text { Gp4b }\end{array}$ & $\begin{array}{c}\text { VSP } \\
\text { Gp4c }\end{array}$ & $\begin{array}{c}\text { VSP } \\
\text { Gp4d }\end{array}$ \\
\hline $\begin{array}{l}\text { Strain } \\
\text { Rabbit serum }\end{array}$ & Ly & Lw & La & Ma & $\begin{array}{c}\mathrm{Ku} \\
+\end{array}$ & $\begin{array}{c}\text { A1 } \\
+\end{array}$ & A5 & A9 & A10 & A12 & A15* & A17 \\
+ & - & - & - & - & + & - & - \\
\hline
\end{tabular}

* B. recurrentis strain A16, which belongs to VSP protein group 4c, was also reactive with the VSP33 antiserum.

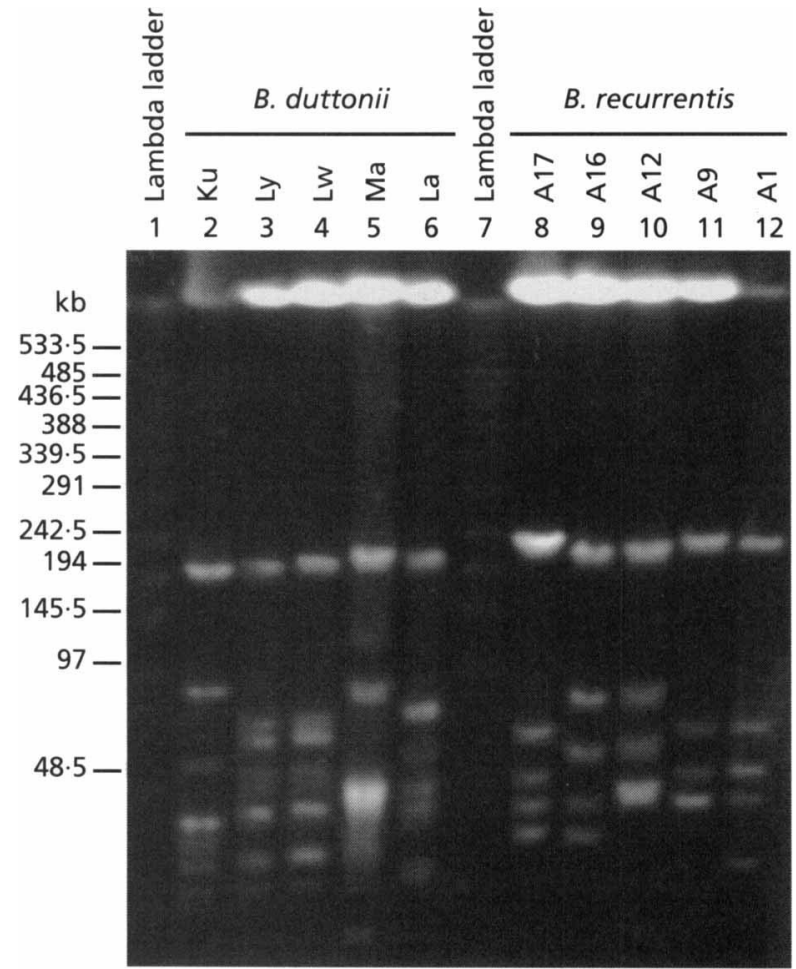

Fig. 2. PFGE patterns of $B$. duttonii compared with those of representative plasmid types of $B$. recurrentis.

duttonii are given in Table 2. The chromosome and large plasmids resolved as sharp bands and thus, like other members of the genus, probably represent linear DNA (Casjens et al., 1995; Ferdows et al., 1996).

\section{rrs gene sequencing}

The four strains of $B$. duttonii gave $100 \%$ identity with each other and $97.9-99.7 \%$ identity with those previously published for this species $(99.7 \%$ homology with three GenBank submissions, but only $97.9 \%$ with sequence U28503). The four base substitutions in the $r r s$ gene previously described for differentiation of $B$. recurrentis from $B$. duttonii were upheld by the
Table 2. Molecular sizes (kb) of plasmids in B. duttonii strains

\begin{tabular}{|rrrrr|}
\hline Lw & Ly & La & Ma & Ku \\
\hline 201 & 199 & 198 & 202 & 202 \\
76 & 74 & 76 & 88 & 90 \\
67 & 67 & 58 & 45 & 59 \\
54 & 52 & 45 & 33 & 38 \\
48 & 47 & 38 & 28 & 33 \\
39 & 38 & 28 & 24 & 29 \\
32 & 31 & 25 & 20 & 26 \\
29 & 28 & 11 & 11 & 23 \\
26 & 25 & & & 11 \\
11 & 11 & & & \\
\hline
\end{tabular}

sequencing results of a further seven strains of $B$. recurrentis. In addition, two of these isolates, A11 and A16, showed a further change. The results for $B$. recurrentis strain $\mathrm{Al}$ in this study revealed an additional cytosine omitted from the previously published sequence (Marti Ras et al., 1996).

\section{$\mathbf{G}+\mathbf{C}$ content of $B$. duttonii DNA}

The $\mathrm{G}+\mathrm{C}$ content of strain Ly was $27.6 \mathrm{~mol} \%$. This is within the range $27-32 \mathrm{~mol} \%$ reported for members of the genus Borrelia (Fukunaga et al., 1995).

\section{Electron microscopy}

Electron microscopy showed characteristic borrelial cells (Fig. 3a). The cells, like B. recurrentis, had tapering ends (Fig. 3a) and a mean wavelength of $1.8 \mu \mathrm{m}$ with an amplitude of $0.9 \mu \mathrm{m}$. Length was variable, but was approximately $13-23 \mu \mathrm{m}$ and cells had a diameter of $0 \cdot 25-0 \cdot 35 \mu \mathrm{m}$ (Fig. 3b, c). Flagella counts on transverse sections showed 10 flagellae (Fig. $3 \mathrm{~b}, \mathrm{c})$. Negatively stained preparations of the central portion of spirochaetal cells showed 18-22 flagellae, presumably with the flagellae released at their point of cross-over (Fig. 3e). Insertion points were distinguished in the negatively stained preparations (Fig. 


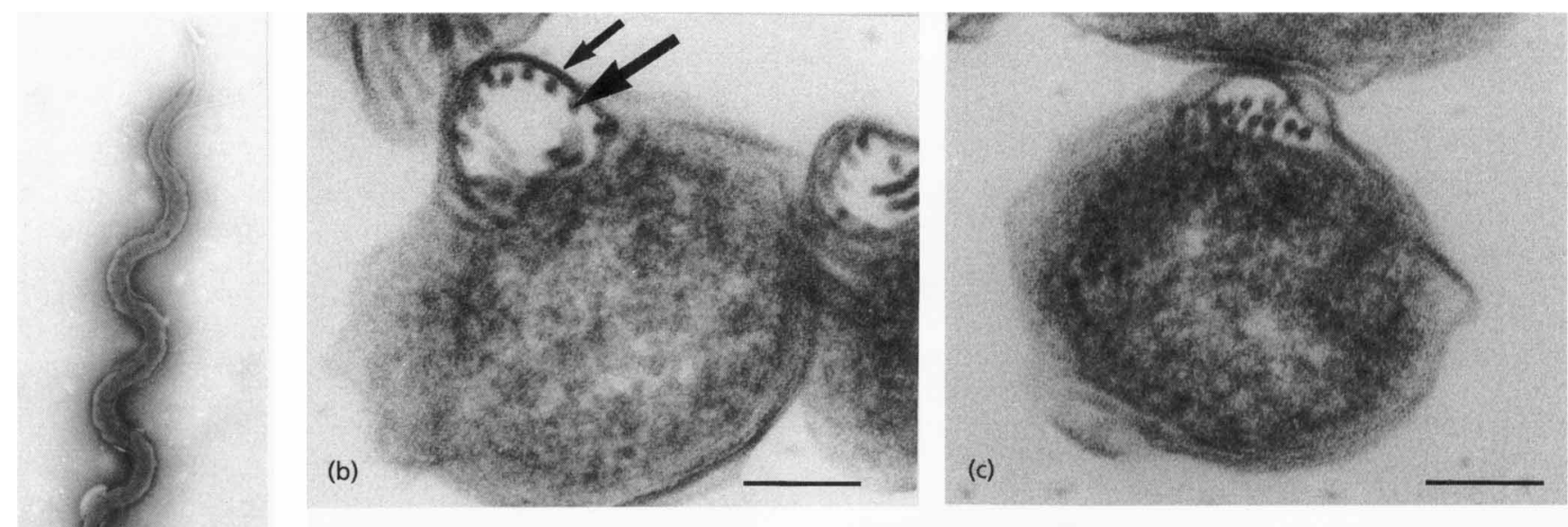

(a)

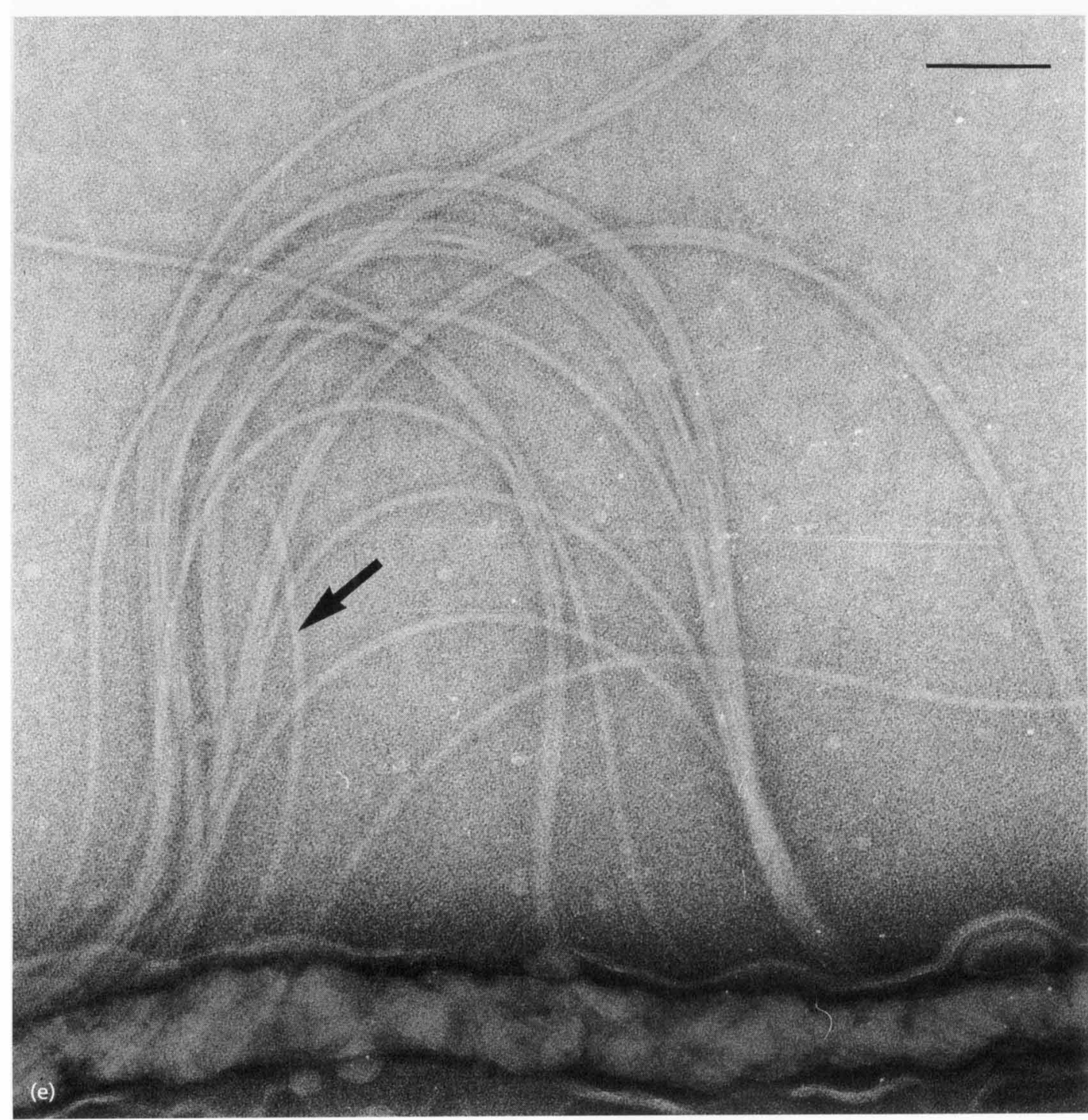

Fig. 3. Electron micrographs of B. duttonii strain Ly. (a) Shows the spirochaetal morphology of cells and tapering ends (negative staining); scale bar, $1 \mu \mathrm{m}$; (b, c) transverse section of cell revealing the periplasmic flagellae, short arrow shows outer membrane while the long arrow marks periplasmic flagellae; scale bar, $0 \cdot 1 \mu \mathrm{m}$; (d) negative-stained preparation showing terminally associated flagellae with insertion points marked by arrow; scale bar, $0.05 \mu \mathrm{m}$; (e) negative-stained preparation showing flagellae associated with the central portion of a cell; scale bar, $0.2 \mu \mathrm{m}$. 
3d), however, no more than three could be resolved in any one frame.

\section{DISCUSSION}

Morphologically, similarity was seen between the $B$. duttonii strains described in this study and $B$. recurrentis reported in earlier literature (Cutler et al., 1997). Electron microscopic results revealed cells with tapering ends (Fig. 3a), typical of those described for the genus Borrelia, however, slightly less pointed than those described for B. burgdorferi (Hovind Hougen, 1984; Hulínská et al., 1989). The length of cells, diameter, wavelength and amplitude of strain Ly were similar to that reported earlier for B. recurrentis (Cutler et al., 1997). Previously, we reported the disparity between our flagella counts of $8-10$ flagella for the A1 strain of $B$. recurrentis with those reported in the literature describing 15-20 and 25-30 unsheathed flagella, respectively (Hovind Hougen, 1974; Hulínská et al., 1989). Similar flagella counts have appeared in the literature for B. duttonii (Barbour \& Hayes, 1986) and recently a tick-borne species of relapsing fever Borrelia from Spain (Anda et al., 1996). The finding of 10 flagella in $B$. duttonii substantiates our earlier findings with $B$. recurrentis and is in keeping with the Lyme-associated members of the genus (Barbour \& Hayes, 1986).

Sequencing studies of the rrs gene for $B$. duttonit confirm the identity of this spirochaete at the nucleotide level. Results of three strains used in an earlier study showed only a single-base difference from our results reported in this paper (Marti Ras et al., 1996) and underline the highly conserved nature of this gene. A fourth strain of $B$. duttonii gave more divergence in its $r r s$ gene sequence with 25 nucleotide differences. The four-base difference that differentiates $B$. duttonii from $B$. recurrentis was upheld by the results of this study. Furthermore, two groups among the $B$. recurrentis strains were identified based on the sequences of their rrs genes.

The PFGE demonstrated the presence of a chromosome of approximately one megabase present in all of the strains tested. This is similar to that described in other borrelial strains analysed (Baril et al., 1989; Bergström et al., 1991; Ferdows et al., 1996; Kitten \& Barbour, 1992). High-molecular-mass plasmids of 180 and $170 \mathrm{~kb}$ have previously been described in $B$. hermsii and Borrelia turicatae respectively (Ferdows et al., 1996) and of slightly larger size (183-194 bp) in B. recurrentis (Cutler et al., 1997). These were also demonstrated in $B$. duttonii by our analysis. The remainder plasmid profile of the $B$. duttonii isolates was very heterogeneous. Two isolates, Ly and Lw, shared the same plasmid profile, and also had major protein bands of the same molecular mass, but the remaining strains failed to show a common pattern.

The serospecificity of Borrelia in each clinical relapse is determined by their variable major proteins (variable large proteins, VLPs, or variable small proteins, VSPs). The VLPs and VSPs present in $B$. hermsii, and indeed other species of spirochaetes causing relapsing fever, are of similar size to those which we have found in both $B$. duttonii and B. recurrentis, VLPs of $33-45 \mathrm{kDa}$ or VSPs of 21.5-24 kDa. Sequencing studies of a portion of the VLP from the A1 strain of $B$. recurrentis have shown greatest similarity with VLP12 of $B$. hermsii (Vidal et al., 1998). This would suggest that the major protein bands detected at 33 to $45 \mathrm{kDa}$ by Coomassie blue staining are homologous to the VLPs of these isolates. An additional low-molecular-mass band of between 19-21 kDa was seen in strains $\mathrm{La}, \mathrm{Ma}$ and $\mathrm{Ku}$ of $B$. duttonii and in strains A 10 of B. recurrentis. It is possible that this may also be VSP-like, reflecting either the uncloned nature of these clinical isolates, or antigenic variation occurring in culture in a subpopulation of cells.

Adaptation of $B$. hermsii to a culture-adapted variant VSP33 has been reported previously (Carter et al., 1994). This VSP showed greater homology with VSPs of similar molecular mass from $B$. hermsii and OspC of B. burgdorferi than it did with other 35-39 kDa VLPs derived from the same isolate (Carter et al., 1994). The findings of this study showed reactivity of polyclonal antisera raised against VSP33 with the VLP of two of three strains of $B$. recurrentis, VSP of one $B$. duttonii and two strains of four $B$. recurrentis demonstrating significant homology among the VLP and VSP proteins of relapsing fever borreliae.

Areas of homology exist between the different VLP and VSP genes of $B$. hermsii and indeed, have been shown to have homology with other relapsing fever species including Borrelia turicatae and Borrelia crocidurae (Cadavid et al., 1997; Burman \& Bergström, 1994; Hinnebusch et al., 1998). Primers designed for amplification of $B$. hermsii VLPs have also amplified VLP genes from $B$. turicatae, Borrelia parkeri, $B$. crocidurae and from the presumptive agent of epizootic bovine abortion, Borrelia coriaceae (Hinnebusch et al., 1998). Sequences of the VLP/VSP genes of $B$. hermsii are similar to those of other Borreliae, namely the OspC protein of B. burgdorferi sensu lato (Marconi et al., 1993; Margolis et al., 1994) and a VLP/VSP-like gene in Borrelia myamotoi (Hamase et al., 1996). This could account for the cross-reactivity seen with antiserum raised against VSP33.

\section{ACKNOWLEDGEMENTS}

We thank the staff of Mvumi Hospital for their assistance and the Special Trustees of Charing Cross Hospital for supporting the visit to Tanzania. We also thank Ian Shore for technical assistance with the electron microscopy.

\section{REFERENCES}

Anda, P., Sánchez-Yebra, W., del Mar Vitutia, M., Pastrana, E. P., Rodríguez, I., Miller, N. S., Backenson, P. B. \& Benach, J. L. (1996). A new Borrelia species isolated from patients with relapsing fever in Spain. Lancet 348, 162-165. 
Barbour, A. G. (1984). Isolation and cultivation of Lyme disease spirochetes. Yale J Biol Med 57, 521-523.

Barbour, A. G. \& Hayes, S. F. (1986). Biology of Borrelia species. Microbiol Rev 50, 381-400.

Barbour, A. G., Barrera, O. \& Judd, R. C. (1983). Structural analysis of the variable major proteins of Borrelia hermsii. J Exp Med 158, 2127-2140.

Barbour, A. G., Hayes, S. F., Heiland, R. A, Schrumpf, M. E. \& Tessier, S. L. (1986). A Borrelia-specific monoclonal antibody binds to a flagellar epitope. Infect Immun 52, 549-554.

Barclay, A. J. \& Coulter, J. B. (1990). Tick-borne relapsing fever in central Tanzania. Trans $R$ Soc Trop Med Hyg 84, 852-856.

Baril, C., Richaud, C., Baranton, G. \& Saint-Girons, I. S. (1989). Linear chromosome of Borrelia burgdorferi. Res Microbiol 140, 507-516.

Bergström, S., Barbour, A. G., Garon, C. F., Hindersson, P., SaintGirons, I. \& Schwan, T. G. (1991). Genetics of Borrelia burgdorferi. Scand J Infect Dis 77, (suppl.) 102-107.

Burman, N. \& Bergström, S. (1994). A variable antigen in the relapsing fever agent Borrelia crocidurae is expressed from a novel expression site. In Antigenic variation in relapsing fever Borrelia, thesis by N. Burman (Umeå University Medical Dissertations, New Series, no. 407). Umeå: Umeå University.

Cadavid, D., Pennington, P. M., Kerentseva, T. A., Bergström, S. \& Barbour, A. G. (1997). Immunologic and genetic analysis of VmpA of a neurotropic strain of Borrelia turicatae. Infect Immun 65, 3352-3360.

Carter, C. J., Bergström, S., Norris, S. J. \& Barbour, A. G. (1994). A family of surface-exposed proteins of 20 kilodaltons in the genus Borrelia. Infect Immun 62, 2792-2799.

Casjens, S., Delange, M., Ley, H. L., III, Rosa, P. \& Huang, W. M. (1995). Linear chromosomes of Lyme disease agent spirochetes: genetic diversity and conservation of gene order. $J$ Bacteriol 177, 2769-2780.

Cutler, S. J., Wright, D. J. M. \& Luckhurst, V. H. (1993). Simplified method for the interpretation of immunoblots for Lyme borreliosis. FEMS Immunol Med Microbiol 6, 281-286.

Cutler, S. J., Fekade, D., Hussein, K., Knox, K. A., Melka, A., Cann, K., Emilianus, A. R., Warrell, D. A. \& Wright, D. J. M. (1994). Successful in-vitro cultivation of Borrelia recurrentis. Lancet 343, 242.

Cutler, S. J., Moss, J., Fukunaga, M., Wright, D. J. M., Fekade, D. \& Warrell, D. (1997). Borrelia recurrentis characterization and comparison with relapsing-fever, Lyme-associated, and other Borrelia spp. Int $J$ Syst Bacteriol 47, 958-968.

Dupont, H. T., La Scola, B., Williams, R. \& Raoult, D. (1997). A focus of tick-borne relapsing fever in southern Zaire. Clin Infect Dis 25, 139-144.

Ferdows, M. S., Serwer, P., Griess, G. A., Norris, S. J. \& Barbour, A. G. (1996). Conversion of a linear to a circular plasmid in the relapsing fever agent Borrelia hermsii. J Bacteriol 178, 793-800.

Fukunaga, M., Takahashi, Y., Tsuruta, Y., Matsushita, O., Ralph, D., McClelland, M. \& Nakao, M. (1995). Genetic and phenotypic analysis of Borrelia miyamotoi sp. nov., isolated from the Ixodid tick Ixodes persulcatus, the vector for Lyme disease in Japan. Int $J$ Syst Bacteriol 45, 804-810.
Hamase, A., Takahashi, Y., Nohgi, K. \& Fukunaga, M. (1996). Homolog of variable major protein genes between Borrelia hermsii and Borrelia miyamotoi. FEMS Microbiol Lett 140, 131-137.

Hinnebusch, J., Barbour, A. G., Restrepo, B. I. \& Schwan, T. G. (1998). Population structure of the relapsing fever spirochete Borrelia hermsii as indicated by polymorphism of two multigene families that encode immunogenic outer surface lipoproteins. Infect Immun 66, 432-440.

Hovind Hougen, K. (1974). Electron microscopy of Borrelia merionesi and Borrelia recurrentis. Acta Pathol Microbiol Scand Sect B 82, 799-809.

Hovind Hougen, K. (1984). Ultrastructure of spirochetes isolated from Ixodes ricinus and Ixodes dammini. Yale J Biol Med 57, 543-548.

Hulínská, D., Jirous, J., Valesová, M. \& Herzogová, J. (1989). Ultrastructure of Borrelia burgdorferi in tissues of patients with Lyme disease. J Basic Microbiol 29, 73-83.

Jongen, V. H. W. M., Van Roosmalen, J., Tiems, J., Van Holten, J. \& Wetsteyn, J. C. F. M. (1997). Tick-borne relapsing fever and pregnancy outcome in rural Tanzania. Acta Obstet Gynecol Scand 76, 834-838.

Kitten, T. \& Barbour, A. G. (1992). The relapsing fever agent Borrelia hermsii has multiple copies of its chromosome and linear plasmids. Genetics 132, 311-324.

Konishi, H., Morshed, M. G., Akitomi, H. \& Nakazawa, T. (1993). In-vitro cultivation of Borrelia duttonii on cultures of Sf1Ep cells. Microbiol Immunol 37, 229-232.

Marconi, R. T., Samuels, D. S., Schwan, T. G. \& Garon, C. F. (1993). Identification of a protein in several Borrelia species which is related to OspC of the Lyme disease spirochetes. $J$ Clin Microbiol 31, 2577-2583.

Margolis, N., Hogan, D., Cieplak, W., Schwan, T. G. \& Rosa, P. A. (1994). Homology between Borrelia burgdorferi OspC and members of the family of Borrelia hermsii variable major proteins. Gene 143, 105-110.

Marti Ras, N., Lascola, B., Postic, D., Cutler, S. J., Rodhain, F., Baranton, G. \& Raoult, D. (1996). Phylogenesis of relapsing fever Borrelia. Int J Syst Bacteriol 46, 859-865.

Melkert, P. W. (1991). Mortality in high risk patients with tickborne relapsing fever analysed by the borrelia-index. East Afr Med $J$ 68, 875-879.

Talbert, A., Nyange, A. \& Molteni, F. (1998). Spraying tick infested houses with lambda-cyhalothrin reduces the incidence of tick-borne relapsing fever in children under five years old. Trans $R$ Soc Trop Med Hyg 92, 251-253.

Vidal, V., Scragg, I. G., Cutler, S. J., Rockett, K. A., Fekade, D., Warrell, D. A., Wright, D. J. M. \& Kwiatkowski, D. (1998). Variable major lipoprotein is a principal TNF-inducing factor of louse-borne relapsing fever. Nat Med 4, 1416-1420.

Walton, G. A. (1962). The Ornithodorus moubata superspecies problem in relation to human relapsing fever epidemiology. In Aspects of Disease Transmission by Ticks (Royal Zoological Society of London Symposium Series), pp. 83-153. London: Royal Zoological Society. 